\title{
Organic Fertilizer Improve the Growth, Physiological Characters and Yield of Pak Choy
}

\author{
Endang Dwi Purbajanti ${ }^{1 *}$ dan Susi Setyowati ${ }^{2}$ \\ ${ }^{1}$ Department of Agroecotechnology, Faculty of Animal and Agricultural Science, Universitas Diponegoro, Semarang, Indonesia; \\ ${ }^{2}$ Field Instructor of Agriculture, Getasan Sub-district, Semarang Regency, Agriculture Ministry, Indonesia \\ *Corresponding author: endang.purbajanti@live.undip.ac.id
}

Received: July 20, 2019; Accepted: September 28, 2020; Published: October 1, 2020

\begin{abstract}
Organic fertilizer expected increase number of growth and yield of pak choy. This research aims to study the influence of solid organic fertilizer and liquid organic fertilizer on growth, physiological characters, and yield of pak choy. The method used was Randomized Complete Design and three replications. The parameters observed were number of leaves, leaf area, chlorophyll content, Nitrate Reductase (NR), yield and harvest index. The result showed that the highest leaf number with 13.3 leaves was achieved by combination of SOF 20 t.ha $^{-1}$ and LOF 3 times a week. The largest leaf area was $208.44 \mathrm{~cm}^{2}$ due to the application of Solid Organic Fertilizer $20 \mathrm{t}^{-\mathrm{ha}^{-1}}$.The largest chlorophyll content was 0.84 mg.g-1 due to the combination treatment of SOF 20 t.ha- $^{-1}$ and LOF 3 times a week. The largest NR of Pak choy is $3.51 \mu$ mol NO2.hr ${ }^{-1}$ due to the combination treatment of SOF 20 t.ha $^{-1}$ and LOF 3 times a week. The highest yields of pak choy is $29.79 \mathrm{~kg}_{\text {. }} \mathrm{ot}^{-1}$ is due to combination treatment SOF of $20 \mathrm{t}^{-}$ha ${ }^{-1}$ and LOF 3 times a week, the highest harvest index was $94.6 \%$ due to combination treatment of SOF 20 t.ha $^{-1}$ and LOF 3 times a week.
\end{abstract}

Key words: chlorophyll, nitrate reductase, number of leaves

Cite this as: Purbajanti, E. D., \& Setyowati, S. (2020). Organic Fertilizer Improve the Growth, Physiological Characters and Yield of Pak Choy. Agrosains : Jurnal Penelitian Agronomi 22(2): 83-87. DOI: http://dx.doi.org/10.20961/agsjpa.v22i2.43112

\section{INTRODUCTION}

Pak Choy is one of favorite Chinese leafy vegetables in Indonesia. Every $100 \mathrm{~g}$ edible part of Pak Choy contains protein $1.7 \mathrm{~g}$, fat $0.2 \mathrm{~g}$, Carbohydrate $3.1 \mathrm{~g}$, vitamins and minerals such as $\beta$-carotene $(2.3 \mathrm{mg})$, vitamin C (53 mg) and Calcium (102 mg) (Priadi and Nuro, 2017). For the recently increased consumption of sprouts containing high contents of health-promoting compounds in North America, North Europe, and Asia, pak choy sprouts were used in this study. Compared than other leafy vegetables, pak choy is especially rich in carotenoids and chlorophylls. In detail, carotenoids accumulate in the leaves and are located mainly in the thylakoids as part of the photosystems (PSs) of the chloroplasts (Frede et al., 2019). Leaves of the crop can from a of transplant, but we recommended it to harvest rosettes after 50 to 60 days from sowing or 30 to 40 days from transplanting (Acikgoz,2016). We need efforts to increase productivity of mustard technology, which is a component of cultivation technology that can produce maximum production. Efforts to increase mustard productivity should be synergized with increasing soil fertility through the addition of fertilizers, especially organic fertilizer. Using organic fertilizers can help modify the microclimate, can increase exchange and increase crop production.

Macro nutrients needed by plants range from $0.5-3 \%$ of plant body weight, while micronutrients in significant amounts, which are several of the plant dry weight. Of all the macro and micro elements that must be available to plants, only $\mathrm{N}, \mathrm{P}$, and $\mathrm{K}$ elements by plants in greater quantities than other elements. Therefore, these three elements of the main (primary) macro nutrients (Yama dan Kartiko, 2020). Application of organic fertilizer can improve soil properties such as physical, chemical and biological soil properties. Organic matter is a loose grain adhesive, plant nutrient source and energy source of most soil organisms (Hartatik et al., 2015). Application of Organic fertilizer can increase the solubility of elements $\mathrm{P}, \mathrm{K}, \mathrm{Ca}$ and $\mathrm{Mg}$, increase $\mathrm{C}$-organic, cation exchange capacity, water absorption, reduce the saturation of $\mathrm{Al}$ and bulk soil density (BD) (Kuntyastuti et al., 2018). Organic fertilizers generally have two forms. The cultivation technology of organic fertilizer is solid, and organic fertilizer is liquid. The composition of a liquid organic fertilizer is differ from one another. There is a liquid organic fertilizer with a complete composition (macro, micro nutrients, microbial biology, and growth regulators (Jasmi et al., 2015). Organic fertilizers can apply in form of solid organic fertilizers (SOF) and can also in the form of liquid organic fertilizer (LOF). LOF is easily absorbed thoroughly by plants compared to SOF. LOF is mostly applied through leaves as foliar liquid fertilizer. One of the advantage of LOF is that it can supply nutrients quickly. Solid organic fertilizer derived from cow manure, C $36 \%$, N $1.48 \%$, P $0.29 \%$, K $0.75 \%$ and $S 0.21 \%$ (Hossaen et al., 2011) and liquid organic fertilizer derived from cow urine containing $C 0.94 \%, N$ $0.24 \%, \mathrm{P} 0.06$ and $\mathrm{K} 0.45 \%$ (Widjajanto et al, 2016). Synthetic chemical fertilizers will have a negative impact 
on the environment, especially can damage and pollute the soil and the environment. Therefore, it is necessary to look for other fertilizing alternatives, namely using natural or organic fertilizers. Organic fertilizer can help to fertilize the plants, not damage the soil and also not even damage to the environment (Hardiansjah et al, 2019) . The role of vegetable plants is very important as a source of vitamins and minerals needed by the body that must meet the nutrition and leaf green substances. To overcome this problem, it is necessary to provide fertilizer that is suitable for pak choy plants. We can do fertilizing in two ways, using synthetic chemical fertilizers and natural (organic) chemical fertilizers. Organic manure can reduce the soil $\mathrm{pH}$ and enhance the electrical conductivity of nutrient absorption (Ahmad et al, 2017). The aim of this research was to study the influence of application of solid organic fertilizer and liquid organic fertilizer on growth and yield of Brassica.

\section{MATERIALS AND METHODS}

The experiment was conducted at the Village, Getasan sub-district, Semarang regency, Indonesia, from September-December, 2016 in Oxisol soil with loam texture. The method used was Randomized Complete Design $3 \times 3$ factorial and three replications. Factor I were solid organic manure $\left(0,10\right.$ and 20 t.ha $\left.^{-1}\right)$; Factor II were application liquid organic fertilizer (application once a week, 2 times a week, 3 times a week).

The soil character are $\mathrm{pH}$ of 5.6 and organic matter of $1.4 \%$; and a bulk density of 1.1 ; while $\mathrm{N}, \mathrm{P}, \mathrm{K}$ content were $0.28 \%, 16 \mathrm{ppm}$ and $18 \mathrm{ppm}$. Solid organic fertilizer (SOF) is compost of cow manure, while liquid organic fertilizer (LOF) is cow urine added by EM4. Provision of LOF by means of 1 part organic fertilizer diluted in 5 parts water. LOF was 2.5 liters per $2.25 \mathrm{~m}^{2}$ for once application. Pak choy were planted, using 24 experimental plots measuring $1.5 \times 1.5 \mathrm{~m}^{2}$, with a spacing of $30 \times 30 \mathrm{~cm}$ so that each plot contained 25 plants.

The parameters observed were number of leaf, leaf area, chlorophyll content, Nitrate Reductase (NR), yields and harvest index. Number of leaf was observed every week until the plant age was 7 weeks (5 weeks after transplanting), leaf area was observed at the age of 7 weeks using a leaf area meter, chlorophyll content was observed at the age of 7 weeks using spectophotometer, nitrate reductase (NR) was observed 2 weeks after transplanting using (calculated from leaf), whereas yields were observed at harvest (7 weeks) by weighing of all of plant in the plot and $\mathrm{HI}$ was calculated of economic yield divided biological yield after harvest (Kemanian et al., 2007). The number of leaves, leaf area, chlorophyll content of the fifth leaf from the tip of the plant, NR activity, yield, root weight, and harvest index were determined. Chlorophyll content was measured in fresh leaf samples. Leaf samples $(0.5 \mathrm{~g})$ were homogenized with acetone $(90 \% \mathrm{v} / \mathrm{v})$, filtered, and made up to a final volume of $50 \mathrm{~mL}$. Chlorophyll concentration was calculated based on the absorbance of the extract measured by a spectrophotometer $645 \mathrm{UV} / \mathrm{Vis}$ and 666 UV/Vis (Purbajanti et al., 2010). Analysis of NR activity was performed according to the methods used by Purbajanti et al (2017).

\section{RESULTS AND DISCUSSION Growth Parameter \\ Leaf Number}

The solid organic fertilizer has a significant impact on leaf number of Pak choy, and the dose of the organic liquid fertilizer significantly affects leaf number of Pak choy. The interaction between the solid organic fertilizer and the organic liquid fertilizer significantly effected leaf number of Pak choy. Fertilizer solid organic fertilizer of 10 t.ha $^{-1}$ and 1-3 times a week applied liquid fertilizer increased the leaf number of Pak choy by $3.47 \%$ to $6.08 \%$ (Table 1). Fertilizer cow manure of 20 t.ha $^{-1}$ and 1-3 times a week applied liquid fertilizer increased the number of leaf of Pak choy by $2.32 \%$ to $6.08 \%$. The number of leaves in SOF20 t.ha-1-LOF3 times a week 13.3 gives an effect that is not different from SOF20 t.ha ${ }^{-1}$-LOF 2 times a week and SOF20 t.ha-1 - LOF 1 time a week but it differ significantly from all treatments applied. The large number of leaves produces more photosynthates because the more the number of chlorophyll leaves there is also more and more distribution (distribution) of light between leaves more evenly. According to Yudhistira et al., (2014 ) suggested that leaves which have high chlorophyll content are expected to be more efficient in capturing sunlight energy for photosynthesis.

Table 1. Leaves number, leaf area, chlorophyll and nitrate reductase affect by SOF and LOF

\begin{tabular}{|c|c|c|c|c|c|}
\hline & Treatment & Leaves number & $\begin{array}{l}\text { Leaf area } \\
\left(\mathrm{cm}^{2}\right)\end{array}$ & $\begin{array}{l}\text { Chlorophyll } \\
\left(\mathrm{mg}^{-1} \mathrm{~g}^{-1}\right)\end{array}$ & $\begin{array}{c}\mathrm{NR} \\
\left(\mu \mathrm{MOLNO}_{2} \cdot \mathrm{g}^{-1} \cdot \mathrm{hr}^{-1}\right)\end{array}$ \\
\hline \multirow[t]{3}{*}{ SOF 0} & LOF 1 time a week & $7.9 \mathrm{~d}$ & 110.0 & $0.24 \mathrm{~g}$ & $0.91 \mathrm{~g}$ \\
\hline & LOF 2 times a week & $9.1 \mathrm{c}$ & 117.7 & $0.28 f$ & $0.92 \mathrm{~g}$ \\
\hline & LOF 3 times a week & $9.8 \mathrm{c}$ & 117.6 & $0.34 \mathrm{e}$ & $0.93 \mathrm{~g}$ \\
\hline \multirow[t]{3}{*}{ SOF 10} & LOF 1 time a week & $11.5 \mathrm{~b}$ & 137.3 & $0.41 d$ & $0.93 \mathrm{~g}$ \\
\hline & LOF 2 times a week & $11.9 \mathrm{~b}$ & 153.7 & $0.42 d$ & $1.81 \mathrm{e}$ \\
\hline & LOF 3 times a week & $12.2 \mathrm{~b}$ & 172.0 & $0.49 c$ & $2.13 d$ \\
\hline \multirow[t]{3}{*}{ SOF 20} & LOF 1 time a week & $12.9 \mathrm{a}$ & 185.0 & $0.60 \mathrm{~b}$ & $2.75 \mathrm{c}$ \\
\hline & LOF 2 times a week & $13.2 \mathrm{a}$ & 208.7 & $0.61 b$ & $3.05 \mathrm{~b}$ \\
\hline & LOF 3 times a week & $13.3 \mathrm{a}$ & 231.7 & $0.84 a$ & $3.51 \mathrm{a}$ \\
\hline SOF 0 & & $8.94 \mathrm{c}$ & $115.11 \mathrm{c}$ & $0.28 \mathrm{c}$ & $0.92 c$ \\
\hline SOF 10 & & $11.84 b$ & $154.33 \mathrm{~b}$ & $0.44 \mathrm{~b}$ & $1.70 \mathrm{~b}$ \\
\hline \multirow[t]{4}{*}{ SOF 20} & & $13.11 \mathrm{a}$ & $208.44 \mathrm{a}$ & $0.68 \mathrm{a}$ & $3.10 \mathrm{a}$ \\
\hline & LOF 1 time a week & $10.85 b$ & $144.11 b$ & $0.42 \mathrm{c}$ & $1.61 \mathrm{c}$ \\
\hline & LOF 2 times a week & $11.42 \mathrm{a}$ & $160.00 \mathrm{ab}$ & $0.44 \mathrm{~b}$ & $1.93 \mathrm{~b}$ \\
\hline & LOF 3 times a week & $11.62 \mathrm{a}$ & $173.78 \mathrm{a}$ & $0.55 \mathrm{a}$ & $2.19 \mathrm{a}$ \\
\hline
\end{tabular}

Note: abc Means within rows without common superscript are different $(\mathrm{P}<0.05)$. 
According to Febriana et al., (2018) because the elements $\mathrm{N}, \mathrm{P}$ and $\mathrm{K}$ as well as other elements contained in liquid organic fertilizer are available and can be absorbed by mustard plants so that the photosynthetic process runs more optimally and the photosynthates produced are also increasingly increased.

\section{Leaf area}

Solid organic fertilizer (SOF) has a significant impact on leaf area of Pak choy, as well as and the dose of the $(\mathrm{OLF})=$ The interaction between the solid organic fertilizer and the organic liquid fertilizer did not significantly effected leaf area of Pak choy. Application Solid Organic Fertilizer 20 t.ha $^{-1}$ of $208.44 \mathrm{~cm}^{2}$ which is significantly different from SOF 10 t.ha $^{-1}$ or SOF 0 t.ha $^{-1}$. Application of Liquid Organic Fertilizer 3 times a week produces a leaf area of $173.78 \mathrm{~cm}^{2}$ which is not significantly different from LOF applications 2 times a week but significantly different from LOF applications 1 time a week. The leaf area $\left(73.82 \mathrm{~mm}^{2}\right)$ were higher in late autumn-early winter period but leaf thickness $(0.33 \mathrm{~mm})$ contents were higher in late winter-early spring period (Acikgoz et al., 2016). Increased leaf area means the ability of leaves to receive and absorb sunlight will be higher so that photosynthates and the resulting energy is also higher. This is supported by Yudhistira et al (2014) the ability of leaves to produce photosynthetic products is determined by the productivity per unit leaf area and total leaf area. The energy produced depends very much on the leaf's internal and external ratios.

\section{Physiological Character The content of chlorophyll}

The results of the ANOVA show that the solid organic fertilizer has a significant impact on chlorophyll content of Pak choy, and the dose of the organic liquid fertilizer significantly affects chlorophyll content of Pak choy. The interaction between the solid organic fertilizer and the organic liquid fertilizer significantly effected chlorophyll content of Pak choy. Chlorophyll content of Brassica because of SOF 20 t.ha $^{-1}$ treatment and LOF 3 times a week has a value of $0.84 \mathrm{mg} . \mathrm{g}-1$ which differ significantly from all treatments given. The total chlorophyll of the okra is increased by 55 to $138.3 \%$ with the increment of compost N from 50 to $150 \mathrm{~kg} \mathrm{~N}$. ha- ${ }^{-1}$. Chlorophyll okra concentration $1.43 \mathrm{mg} . \mathrm{g}-1$ when given $\mathrm{N}$ compost $150 \mathrm{~kg}$ $\mathrm{N}$. ha- ${ }^{-1}$ (content $(0.17 \%)$ which is differ significantly from administration of $0.50,100 \mathrm{~kg} \mathrm{~N} \cdot \mathrm{ha}^{-1}$ (Purbajanti et al, 2019). Panicum $(1.85 \mathrm{mg} / \mathrm{g}$ of leaf) showed highest chlorophyll content while king grass $(0.92 \mathrm{mg}$. g- 1 of leaf) showed the lowest chlorophyll content. The increasing concentration of $\mathrm{NaCl}$ up to 300 $\mathrm{mM}$ decreased content of chlorophyll $37 \%$ from control $1.59 \mathrm{mg} . \mathrm{g}$ leaf (Purbajanti et al. 2010). Nitrogen is a constituent of chlorophyll. Chlorophyll dose not only affect photosynthesis. But also takes part in the fruit color. The biosynthesis of chlorophyll, interconversion and degradation of chlorophyll content $\mathrm{a} / \mathrm{b}$. In addition, we observed it that the chlorophyll binding condition also influence the degradation of chlorophyll. Therefore, chlorophyll metabolism consists of four main section; the synthesis chlorophyll, chlorophyll $a / b$ interconversion, chlorophyll bond, and chlorophyll degradation (Purbajanti et al, 2016).

\section{Nitrate reductase (NR)}

The results of the ANOVA show that the solid organic fertilizer has a significant impact on NR of Pak choy, and the dose of the organic liquid fertilizer significantly affects NR of Pak choy. The interaction between the solid organic fertilizer and the organic liquid fertilizer significantly effected NR of Pak choy. NR of Pak choy because of combination treatment SOF 20 t.ha $^{-1}$ and LOF 3 times a week have a value of $3.51 \mu \mathrm{mol} \mathrm{NO}_{2}$. hr-1 which is differ significantly from all treatments given. NR of Rice was $4.33 \mu \mathrm{mol} \mathrm{NO} \mathrm{Nar}^{-1}$ in saturated water and $\mathrm{NR}$ was $3.15 \mu \mathrm{mol} \mathrm{NO} 2 . \mathrm{hr}^{-1}$ in field capacity (Purbajanti et al, 2017). Nitrogen in soil are taken by plants mainly in the form of nitrate ions and ammonium ions. The increasing number of nitrate ions in the leaf tissue will further increase NR. This is under the opinion of Daryanto et al, (2011) that the higher content of substrate nitrate in the tissue, the more increase the NR rate.

\section{Yields}

The marketable yields was determined. Harvest was performed only once in particular growing periods, specifying the mass of leaves. The leaves which were fully developed and without damages as they are marketable.

Table 2. Yields and harvest index affect by SOF and LOF

\begin{tabular}{|c|c|c|c|}
\hline & atment & Yields & Harves \\
\hline SOF 0 & $\begin{array}{l}\text { LOF } 1 \text { time a } \\
\text { week }\end{array}$ & $691.75 \mathrm{~g}$ & $85.0 \mathrm{e}$ \\
\hline & $\begin{array}{l}\text { LOF } 2 \text { times a } \\
\text { week }\end{array}$ & $1325.00 \mathrm{f}$ & $86.9 \mathrm{~d}$ \\
\hline & $\begin{array}{l}\text { LOF } 3 \text { times a } \\
\text { week }\end{array}$ & $1600.00 \mathrm{e}$ & $87.4 \mathrm{~d}$ \\
\hline SOF 10 & $\begin{array}{l}\text { LOF } 1 \text { time a } \\
\text { week }\end{array}$ & $1883.25 \mathrm{~d}$ & $88.0 \mathrm{~cd}$ \\
\hline & $\begin{array}{l}\text { LOF } 2 \text { times a } \\
\text { week }\end{array}$ & $2025.00 \mathrm{~d}$ & $89.2 b c$ \\
\hline & $\begin{array}{l}\text { LOF } 3 \text { times a } \\
\text { week }\end{array}$ & $2375.00 \mathrm{c}$ & $89.9 \mathrm{~b}$ \\
\hline SOF 20 & $\begin{array}{l}\text { LOF } 1 \text { time a } \\
\text { week }\end{array}$ & $2553.50 \mathrm{bc}$ & $90.3 \mathrm{~b}$ \\
\hline & $\begin{array}{l}\text { LOF } 2 \text { times a } \\
\text { week }\end{array}$ & $2702.75 b$ & $93.3 \mathrm{a}$ \\
\hline & $\begin{array}{l}\text { LOF } 3 \text { times a } \\
\text { week }\end{array}$ & $2979.00 \mathrm{a}$ & $94.6 \mathrm{a}$ \\
\hline SOF 0 & & $1205.50 \mathrm{c}$ & $86.44 \mathrm{c}$ \\
\hline SOF 10 & & $2094.50 \mathrm{~b}$ & $89.06 \mathrm{~b}$ \\
\hline SOF 20 & & $2745.00 \mathrm{a}$ & $92.76 \mathrm{a}$ \\
\hline & $\begin{array}{l}\text { LOF } 1 \text { time a } \\
\text { week }\end{array}$ & $1709.50 \mathrm{c}$ & $87.79 b$ \\
\hline & $\begin{array}{l}\text { LOF } 2 \text { times a } \\
\text { week }\end{array}$ & $2017.50 \mathrm{~b}$ & $89.98 \mathrm{a}$ \\
\hline & $\begin{array}{l}\text { LOF } 3 \text { times a } \\
\text { week }\end{array}$ & $2318.00 \mathrm{a}$ & $90.49 \mathrm{a}$ \\
\hline
\end{tabular}

Note: abc means within rows without common superscript are different $(\mathrm{P}<0.05)$.

The results of the ANOVA show that the solid organic fertilizer has a significant impact on yields of Pak choy, and the dose of the organic liquid fertilizer significantly affects yields of Pak choy. The interaction between the solid organic fertilizer and the organic liquid fertilizer significantly effected yields of Pak choy. SOF 20 t.ha $^{-1}$ and LOF 3 times a week have a value of $2979.00 \mathrm{~kg}$ which differ significantly from all treatments given (Table 2). According to La Sarido and Junia (2017), with the 
increase in metabolic productivity, plants will need more nutrients and increase water absorption, this is related to the needs of plants during growth and development. Yield characteristics investigated by season and relatively higher in late autumn-early winter than late winter-early spring growing period. It was 5.713 t.ha $^{-1}$ in late autumn-early winter growing period and 5.034 t.ha-1 in late winter-early spring growing period. In this experiment, pak choy responded positively to plantings in late autumn-early winter. It grew plants in lower temperatures and less intensive sunlight, therefore they resulted in higher yields. It state significant effect of growing period on the yield and quality for many Brassicaceae species: leafy cultivars of Brassica rapa, broccoli, red cabbage, cauliflower, Brussels sprouts and Brassica rapa var. narinosa, Acikgoz FE (2016). Pakchoy mustard plants need high availability of nutrients to encourage plant metabolism so it can produce maximum crop production (Hadiyati et al, 2020).

\section{Harvest Index}

The results of the ANOVA show that the solid organic fertilizer has a significant impact on harvest index of Pak choy, and the dose of the organic liquid fertilizer significantly affects harvest index of Pak choy. The interaction between the solid organic fertilizer and the organic liquid fertilizer significantly effected harvest index Pak choy. Harvest index of Pak choy because of SOF 20 t.ha $^{-1}$ treatment and LOF 3 times a weak have a value of $94.6 \%$ which differ significantly from all treatments given. Stevenson (1994) explains that the results of decomposition of organic matter in the soil can increase the availability of nutrients $\mathrm{N}, \mathrm{S}$ and $\mathrm{P}$, increase the power of storing water, increase soil buffering power, increase cation exchange, and improve soil texture. Santosa (1995) explains that the availability of N, P and $S$ nutrients can spur plant growth. $P$ nutrients for plants function as constituents of plasma membranes, nucleic acids, phospholipids and monosaccharides while $S$ nutrients function as constituents of amino acids, vitamins (biotin, thimin) and coenzyme A.

\section{Relationship between NR and Yield}

The regression analysis of NR on Brassica yields is expressed by the model equation $Y=6.3397 x+8.2184$ $\left(R^{2}=0.8076\right)$. The model showed that each increase of one unit of NR results in an increased yields of 6.3397 units. $R^{2}$ showed that $80.76 \%$ of the variations in $(Y)$ by NR (Figure 1.) The application of solid organic fertilizers and liquid organic fertilizer influences the physical and chemical properties of soil and enhances the biological activities. It is also positively correlated with soil porosity and enzymatic activity. Applications of both chemical and organic fertilizers need to be applied for the improvement of soil physical properties and supply of essential plant nutrients for higher yields.( Hossaen et al, 2011).

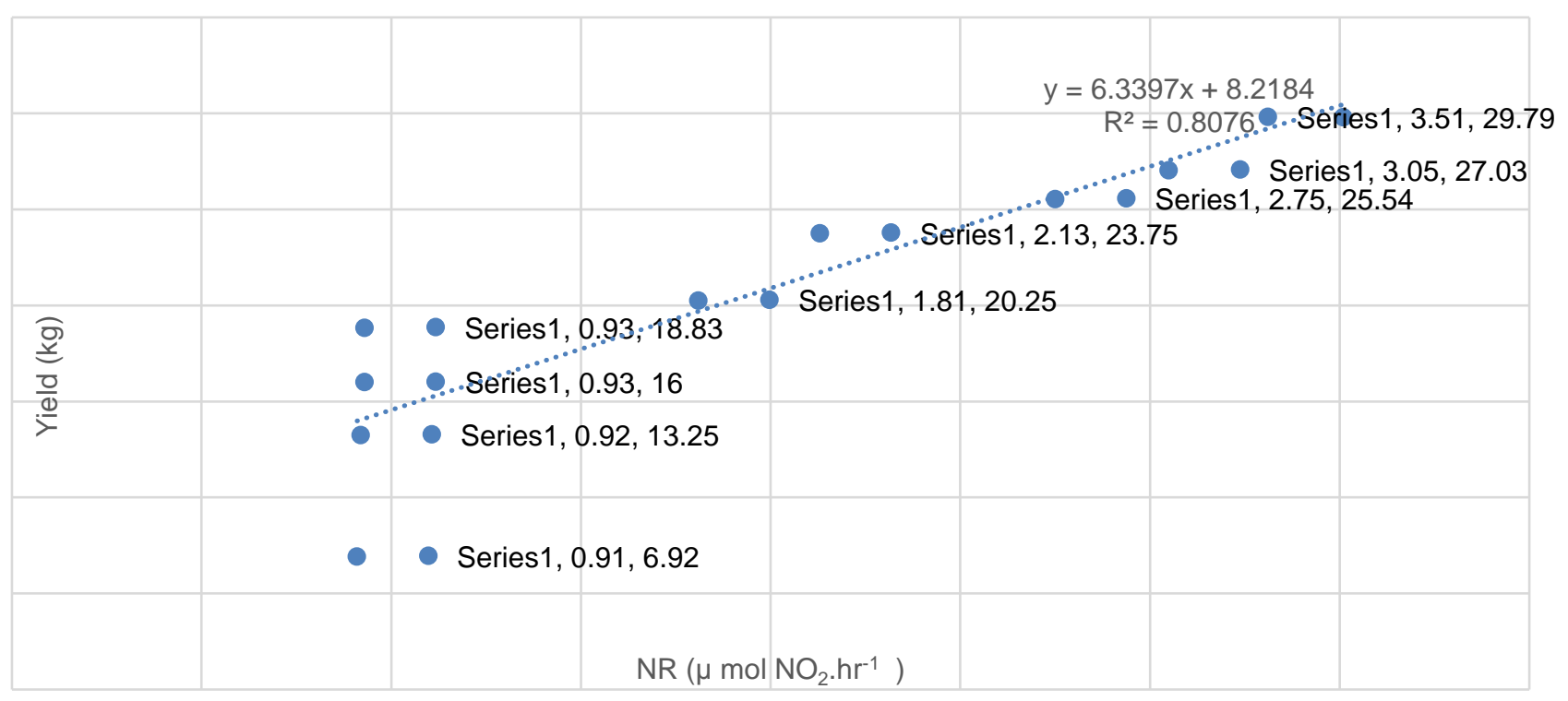

Figure 1. Relationship between NR and Yield

\section{CONCLUSION}

Combination of SOF 20 t.ha $^{-1}$ treatment and application of liquid organic fertilizer 3 times a week has the best number of leaves, chlorophyll content, NR, yields, and Harvest Index. The highest leaf area on SOF 20 t.ha $^{-1}$ and the application of liquid fertilizer 3 times a week. There is a positive relationship between NR and results.

\section{REFERENCES}

Acikgoz, F.E. (2016). Seasonal Variations on Quality Parameters of Pak Choi (Brassica rapa L. subsp. chinensis L.). Adv Crop Sci Tech 4: 233. doi:10.4172/2329-8863.1000233 .
Ahmad, T., Shah, S.T., Ullah, F., Ghafoor F. \& Anwar, U. (2017). Effect of organic fertilizer on growth and yield of coriander. Int. J. Agri and Env. Res., 3(1): 116-120

Daryanto, Indraderva, D., Radjagukguk, B. \& Taryono. (2011). Nitrogen utilization parameters of rice field genotype. Agronomika II(1). Januari 2011

Febrianna,M., Prijono, S. \& Kusumarini, N. (2018). The use of Liquid Organic Fertilizer to Increase Nitrogen Uptake and Growth and Yield of Mustard (Brassica juncea L.) on Sandy Soil. Jurnal Tanah dan Sumberdaya Lahan 5(2): 1009-1018.

Fredea, K., Schreinera, M. \& Baldermann, S. (2019). Light quality-induced changes of carotenoid 
composition in pak choi Brassica rapa ssp. Chinensis. Journal of Photochemistry \& Photobiology, B: Biology 193 (2019) 18-30.

Hadiyati, A. F., Slamet, W. \& E. D. Purbajanti. (2020). Growth and production of pakchoy plant (Brassica chinensis L.) in variant of bioslurryfertilizer dosage and plant spacing. J. Agro Complex 4(1):32-39. DOI: https://doi.org/10.14710/joac.4.1.32-39

Hardiansyah, P., Nurjanah, U. \& Widodo. (2019). Growth response and yield of pakcoy (Brassica rapa L.) on various concentrations of liquid organic fertilizer of Jering Pods. Akta Agrosia 22(1):43-49

Hartatik, W., Husnain \& Widowati, L. R. (2015). Role of Organic Fertilizer to Improving Soil and Crop Productivity. Jurnal Sumberdaya Lahan 9(2):107-120.

Hossaen, M. A., Shamsuddoha, A. T. M., Paul, A. K., Bhuiyan, M. S. I. \& Zobaer, A. S. M. (2011). Efficacy of Different Organic Manures and Inorganic Fertilizer on the Yield and Yield Attributes of Boro Rice. The Agriculturists 9(1\&2): 117-125.

Jasmi, Mahdjali, S. \& Gunawan, J. (2015). The effect of concentration and time interval giving of liquid organic fertilizer (poc) and sea horse towards the growth and yield of eggplant plant (Vigna sinensis L.). Jurnal Agrotek Lestari 1(1): 35-45.

Kemanian, A. R., Stockle, C. O., Huggins, D. R. \& Viega, L. M. (2007). A simple method to estimate harvest index in grain crops. Field Crops Research 103 (2007) 208-216. DOI:10.1016/j.fcr.2007.06.007

Kuntyastuti, H., Lestari, S. A. D. \& Sutrisno. (2018). Effects of organic fertilizer and plant spacing on earlymedium maturity soybean. J. Degrade. Min. Land Manage. 5(3): 1171-1179, DOI: 10.15243/jdmIm.2018.053.1171.

La Sarido dan Junia. (2017). Uji pertumbuhan dan hasil tanaman Pakcoy (Brassica rapa L.) dengan pemberian pupuk organic cair pada system hidroponik . Jurnal AGRIFOR XVI (1), Maret 2017

Priadi, D. \& Nuro, F. (2017). Seedling production of Pak Choy (Brassica rapa L.) using organic and inorganic nutrients. Biosaintifika: Journal of Biology \& Biology Education, 9(2):217-224.
Purbajanti, E .D., Soetrisno, R. D., Hanudin, E. \& Budhi, S. P. S. (2010). Photosynthesis and yields of grasses grown in saline condition. Indonesian Trop. Anim. Agric. 35(1).

Purbajanti, E. D., Kusmiyati, F., Slamet, W., Darmawati, A. \& Roessali, W. (2016). Differences in Crop Growth Rate, Chlorophyll Content Index and Nitrate Reductase in Source $\mathrm{N}$ of Sweet Corn. International Proceedings of Chemical, Biological and Environmental Engineering, 92:23-26. DOI: I0.776irlPcBEE. 2016. Vol. 92. 4.

Purbajanti, E. D., Kusmiyati, F. \& Fuskhah, E. (2017). Growth, Yield, Physiological Characters of three types of Indonesia Rice under Limited Water Supply. Asian J.Plant Sci, 16: 101-108.

Purbajanti, E. D., Slamet, W. \& Fuskhah, E. (2019). Nitrate reductase, chlorophyll content and antioxidant in okra (Abelmoschus esculentus Moench) under organic fertilizer. Journal of Applied Horticulture, 21(3): 213-217.

Santosa. 1995. Ilmu Hara. Fakultas Biologi Universitas Gadjah Mada, Yogyakarta

Steel, R. G. D. \& Torrie, J. H. 1990. Principles and Procedures of Statistic. John Wiley and Sons, New York.

Stevenson, F. J. (1994). Humus, Chemystry, Genesis, Compositions, Reactions. John Willy \& Sons, New York

Widjajanto, D. W., Cahya S. U., Purbajanti, E. D., Christiyanto, M., Haroeno, T. W. \& Santoso, A. (2016). Aplikasi pupuk hayati limbah hijauan pertanian pada kluster Biofarmaka Kabupaten Semarang. Prosiding Seminar Nasional Mikrobiologi II UKSW. Kerjasama Prodi Biologi Fakultas Biologi, UKSW dengan PERMI CbBng Solo, hal. 122-126.

Yama, D. I. \& Kartiko, H. (2020). Growth and cholophyll content pak choy (Brassica rappa L) under concentration of $A B$ Mix system Wick. Jurnal Teknologi 12(1): 21-30.

Yudhistira, P. G., Roviq, M. \& Wardiyanti, T. (2014). Growth and Productivity Pak Choy Mustard (Brassica rapa L.) at Transplanted Age and Organic Mulch Application. Jurnal Produksi Tanaman 2(1):41-49. 